\title{
Morpho-Agronomical and Nutritional Evaluation of Cultivated Einkorn Wheat (Triticum monococcum L. ssp. monococcum) Lines Sown in Autumn and Spring Seasons
}

\author{
Servet Kefi ${ }^{*}$, Orhan Kavuncu ${ }^{2}$, Engin Bıyıklı ${ }^{3}$, Ayten Salantur ${ }^{4}$, Mehmet Emin Alyamaç ${ }^{5}$, \\ Asuman Kaplan Evlice ${ }^{6}$, Aliye Pehlivan ${ }^{7}$ \\ ${ }^{1}$ Department of Genetics and Bioengineering, Faculty of Engineering and Architecture, \\ Kastamonu University, Kastamonu, Turkey \\ *Corresponding author's email: servet.kefi [AT] gmail.com
}

2Department of Genetics and Bioengineering, Faculty of Engineering and Architecture,

Kastamonu University, Kastamonu, Turkey

Email: orhankavuncu [AT] kastamonu.edu.tr

3̇ihsangazi Directorate of Agriculture and Forestry, İhsangazi, Kastamonu, Turkey

Email: engin.biyikli [AT] tarimorman.gov.tr

\footnotetext{
${ }^{4}$ Central Research Institute for Field Crops, Şehit Cem Ersever Cad., No. 9-11, Yenimahalle, Ankara, Turkey Email: ayten.salantur [AT] tarimorman.gov.tr

${ }^{5}$ Central Research Institute for Field Crops, Şehit Cem Ersever Cad., No. 9-11, Yenimahalle, Ankara, Turkey Email: mehmetemin.alyamac [AT] tarim.gov.tr

${ }^{6}$ Central Research Institute for Field Crops, Şehit Cem Ersever Cad., No. 9-11, Yenimahalle, Ankara, Turkey Email: asuman.kaplanevlice [AT] tarim.gov.tr

${ }^{7}$ Central Research Institute for Field Crops, Şehit Cem Ersever Cad., No. 9-11, Yenimahalle, Ankara, Turkey Email: aliye.pehlivan [AT] tarim.gov.tr
}

\begin{abstract}
Nowadays diploid einkorn wheat (Triticum monococcum L. ssp. monococcum), widely cultivated in the Neolithic age, has been reconsidered as the valuable genetic resource for breeding and organic farming due to its high resistance to pests and diseases, adaptation to harsh climates, ability to provide acceptable yields on poor soils even with low/without inputs and high nutritional values. In this research, local 45 cultivated einkorn lines, selected from 500 single rows planted by each single spikes collected from total 50 farmers' fields in 34 villages of Kastamonu/Turkey, were evaluated in terms of their morpho-agronomical traits and nutritional characteristics during two sowing seasons, autumn 2017 and spring 2018. Einkorn lines sown in two different seasons showed significant variations for heading time, plant height, lodging susceptibility, spike length, number of spikelets per spike, gross grain yield, amount of glume, single kernel weight, kernel diameter, hardness index, grain protein content and the color $(a, b, L)$ values of flour. Furthermore, most of the correlation coefficients between these characteristics were found to be significant. All lines showed "facultative" growth habit, flowering well when sown both in autumn and in spring. Although lines sown in autumn had more yields, the same lines sown in spring provided higher grain quality and more resistance to lodging due to having shorter stems. In order to enable sustainable future use of einkorn, further research is suggested for reduction of plant height to avoid lodging and improvement of grain yield to compete with modern high yielding wheat cultivars.
\end{abstract}

Keywords - einkorn wheat, sowing season, morpho-agronomical traits, nutritional characteristics

\footnotetext{
ABBREVIATIONS: aCV - a color value, AG - amount of glume (\%), ANOVA - analysis of variance, Avg. - average, $\mathrm{bCV}$ - b color value, CV - coefficient of variation $(\%), \mathrm{GD}$ - grain diameter $(\mathrm{mm}), \mathrm{GGY}$ - gross grain yield per plot $(\mathrm{g}$ $\left.0.99 \mathrm{~m}^{-2}\right), \mathrm{GMC}$ - grain moisture content (\%), GPC - grain protein content (\%), HI - hardness index (\%), HT - heading time (number days from sowing to time of spike emergence), LCV - L color value, LS - lodging susceptibility, MS- mean square, NSS - number of spikelet per spike, PH - plant height (cm), SGW - single grain weight (mg), SKCS - Single Kernel Characterization System, SL - spike length without awn (cm), TARM - Central Research Institute for Field Crops.
} 


\section{INTRODUCTION}

Cultivated einkorn (Triticum monococcum L. ssp. monococcum) is a diploid AA genome wheat $(2 n=2 x=14)$. The name einkorn, implies "single grain" in German language due to the presence of only one grain per spikelet, has been used for both cultivated and wild forms [1]. Having nonthreshable grains, einkorn belongs to the group of cultivated "hulled wheats" [2]. On the other hand, a hulless einkorn form was distinguished in 1970 from a population collected by Zhukovsky in the northern coastal zones of Turkey [3]. This naked form, defined as var. sinskajae (A. Filat. et Kurk.) by [4], has soft glume controlled by a single gene "Sog" mapped by [5].

Einkorn is one of the first crops domesticated in the Fertile Crescent approximately 9500-10000 years ago [6]. It was domesticated in Karacadağ mountains of South-East Anatolia in Turkey [7] and then spread in mountainous areas characterized by relatively wet and cold weather conditions in the Caucasus, the Balkans and Central Europe [8]. Domestication of wild forms by humans gave rise to considerable changes in their physiological and morphological characteristics [9]. Through the structure of its tenacious glumes, einkorn has been well adapted to poor soils and harsh climates and is resistant against diseases and pests [10]. Einkorn grains contain high levels of protein and minerals with low levels of carbohydrate. Compared to modern wheat varieties, einkorn grains have two times more carotenoids, three to four times more lutein and four to five times more riboflavin [11]. Due to these valuable properties, it has been reintroduced in some countries especially for organic farming systems and processing of natural foods [12].

Although einkorn was replaced by free-threshing and higher yielding modern wheat varieties, today it has been still cultivated for both human and animal consumption mainly in restricted marginal areas of Turkey, the Balkan Peninsula, Central and South-West Europe and Morocco. Nowadays in Turkey, einkorn has been grown in the villages of Kastamonu, Bolu, Samsun, Sinop and Karabük provinces in the Black Sea Region and its grains have been processed as mainly Siyez bulgur \& flour. The glumes removed from kernels before processing, which comprise roughly $30 \%$ of grains, have been used by farmers as animal feed together with straws and organic fertilizer. As well as other wheat landraces, einkorn cultivated in Turkey has been maintained as populations characterized by considerable genetic and phenotypic variations [13].

Landraces, also called farmers' varieties, are defined as traditional crop varieties developed by farmers through many years of human and natural selection and are well adapted to local environmental conditions and cultivation practices [14]. In comparison with modern genetically uniform cultivars, landraces usually have a broader genetic base and provide valuable characteristics important for breeding, such as tolerance to biotic and abiotic stresses, adaption under low-input and organic farming systems and quality traits [15]. Therefore, development of new varieties from landrace populations is a viable strategy to improve landrace yield and yield stability to meet the future needs of sustainable agriculture in the context of climate change conditions [16].

The results presented here were obtained as part of a project aimed at forming the pre-breeding materials to develop einkorn varieties by using genetic variations of existing landraces in Kastamonu, Turkey. By sowing in autumn and in spring of local 45 cultivated einkorn lines, the main objectives of this study were: (i) to determine whether significant variations in terms of morpho-agronomical, physical and nutritional characteristics would arise between 45 different lines and two different sowing seasons, (ii) to examine whether all these traits would present correlations.

\section{MATERIALS AND METHODS}

\subsection{Description of Experimental Sites}

Kastamonu province, the primary einkorn production area of Turkey, is located in the Black Sea Region, North Transition Zone $\left(41^{\circ} 23^{\prime} 19^{\prime \prime} \mathrm{N}, 33^{\circ} 46^{\prime} 57^{\prime \prime} \mathrm{E}\right)$ and has terrestrial climatic conditions, i.e. winters are long, cold and snowy, whereas summers are short and warm. Even though einkorn in Kastamonu generally has been sown in autumn, these sowings can be renewed in spring if the emergence and growth of plants are damaged due to unfavorable climatic conditions.

\subsection{Collection of Einkorn Materials}

In order to form einkorn pre-breeding materials, 500 single spikes were collected during 2016 summer from total 50 farmers' fields growing einkorn landraces in 34 villages having different ecological conditions and altitudes (772-1391 m above the see level) of İhsangazi, Kastamonu Center, Seydiler and Devrekani districts, the main einkorn production areas of Kastamonu (Figure 1). Seeds of each single spikes were sown by hand in a "single row" at Haymana, Ankara Research 
Farm of Central Research Institute for Field Crops (TARM) on October 26, 2016. After evaluation of 500 einkorn lines, 45 lines having favorable morpho-agronomical traits were selected as the pre-breeding materials on August 11, 2017.

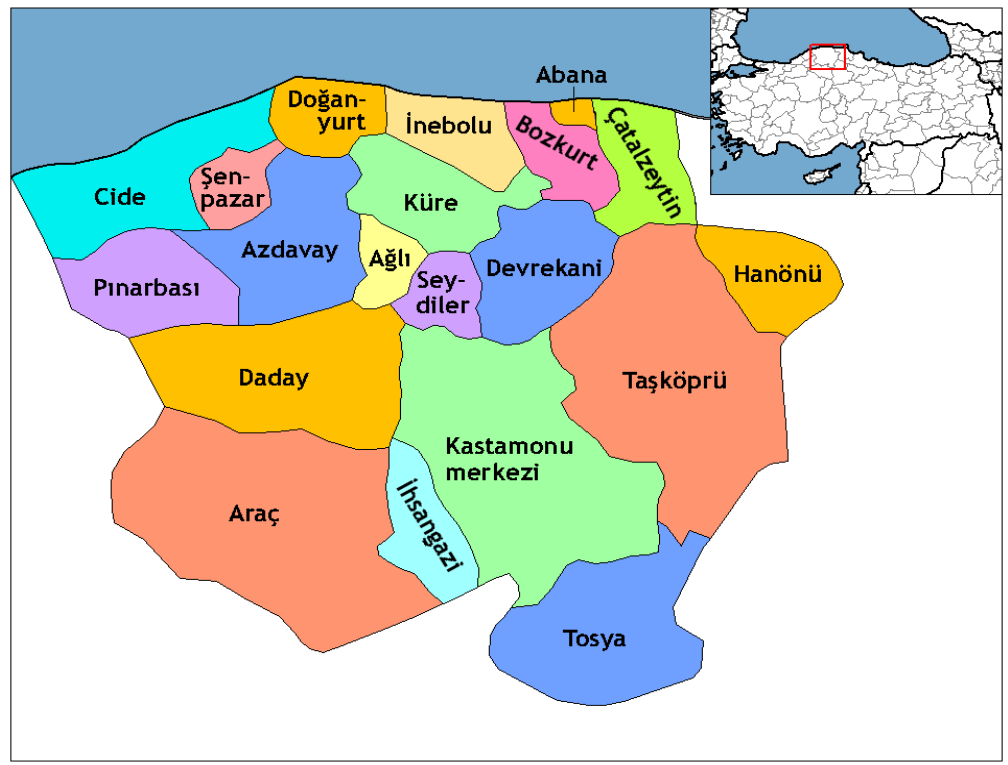

Figure 1: Map of Kastamonu, Turkey where einkorn spikes were collected from total 50 farmers' fields in 34 villages of İhsangazi, Kastamonu Center, Seydiler and Devrekani districts during 2016 summer.

\subsection{Field Trials}

Trials to evaluate 45 einkorn lines in two different sowing seasons were conducted in the same farmer's field having 905 m elevation in İhsangazi district of Kastamonu on November 9, 2017 for autumn sowing and on February 20, 2018 for spring sowing. Due to lack of registered einkorn variety in Turkey yet, three registered durum wheat (T. durum L.) varieties were used as check materials. Each einkorn line and check variety were sown by hand in two rows which $1.50 \mathrm{~m}$ long and $0.33 \mathrm{~m}$ apart with total $0.99 \mathrm{~m}^{2}$ plot size with unreplicated design [17]. Three hundred seeds $(\approx 13 \mathrm{~g})$ for each einkorn line and $10 \mathrm{~g}$ seeds for each check variety were used in each plot. In accordance with the local fertilization application for einkorn cultivation, nitrogen $\left(40 \mathrm{~kg} \mathrm{ha}^{-1} \mathrm{~N}\right)$ and phosphorus $\left(40 \mathrm{~kg} \mathrm{ha}^{-1} \mathrm{P}_{2} \mathrm{O}_{5}\right)$ fertilizers were applied on plots before sowing and no more fertilization applied at tillering. Weeds in the trials were removed by hand and hoe in order to avoid any harm arisen from herbicide application. Plants in the trials of sowing in autumn and spring seasons were harvested by hand in each plot on July 30-31, 2018 and August 8, 2018, respectively.

During the period of field trials between November 2017-August 2018 in İhsangazi, minimum temperatures of $-8.1^{\circ} \mathrm{C}$ (January) and $-7.1^{\circ} \mathrm{C}$ (February), and maximum temperatures of $34.8^{\circ} \mathrm{C}$ (June) and $33.9^{\circ} \mathrm{C}$ (July) were recorded. Total precipitation in this period was $465.4 \mathrm{~mm}$ in which the highest precipitations occurred in March (101.3 mm) and July (84.2 $\mathrm{mm}$ ) (source of data: Kastamonu Meteorology Station). The soil texture of experimental area has clay loam and slightly alkaline reaction [18].

\subsection{Assessment of Morpho-Agronomical Traits} [19].

Total six morpho-agronomical traits were assessed in the field trials according to UPOV Test Guidelines for wheat

- Heading time (HT): number of days from sowing to time of spike emergence that the first spikelet is visible on spikes of $50 \%$ of the plants in each plot.

- Lodging susceptibility (LS): $0=$ no lodging; $3=$ little lodging; 5=moderate lodging; $7=$ very lodging, observed just prior to harvest.

- $\quad$ Plant height $(\mathrm{PH})$ : from ground level to end of spike excluding awns at maturity $(\mathrm{cm})$.

- $\quad$ Spike length (SL): length of spikes excluding awns at maturity (cm).

- Number of spikelet per spike (NSS): counted at maturity.

- Gross grain yield per plot (GGY): the yield of grains with adhering glumes per plot, measured after harvest ( $\mathrm{g}$ $\left.0.99 \mathrm{~m}^{-2}\right)$.

Five plants were randomly selected from each plots for biometrical measurements of PH, SL and NSS. 


\subsection{Evaluation of Physical and Nutritional Characteristics}

All quality analyses were performed at the Department of Food Technology in TARM. Harvesting einkorn samples were hulled with a huller (LH 5095, Codema, USA) and amount of glume (AG) was calculated as \%. Then, grain diameter (GD) as mm, single grain weight (SGW) as mg, grain moisture content (GMC) as \% and hardness index (HI) as \% $(+90=$ extra hard; $81-90=$ very hard; $65-80=$ hard; $45-64=$ medium hard; $35-44=$ medium soft; $25-34=$ soft; $10-24=$ very soft; $\leq 10=$ extra soft) of hulless samples were determined according to the American Association of Cereal Chemists International (AACCI) Standard Method No:55-31 by using the instrument Single Kernel Characterization System (SKCS) 4100 (Perten Instruments, Huddinge, Sweden) [20].

After SKCS analysis, a small amount of wheat sample was ground to the meal (Perten 3100, Huddinge, Sweden) to determine grain protein content (GPC) as \%. The GPCs were identified according to AACCI Standard Method No:46-30 [20] and the conversion factor for protein analysis was Nx5.7. Then, the wheat samples were milled to flour by Brabender Quadrumat Junior (Duisburg, Germany) according to AACCI Method 26-50 [20]. The color a, b and L values (aCV, bCV, LCV) of flour samples were determined by using spectrophotometer (Gardner Color view, USA) based on Hunter Lab colorimeter [21]. All quality analyses for total nine physical and nutritional characteristics were performed in duplicate and results were expressed on dry weight basis.

\subsection{Statistical Analysis}

Differences and correlations (linear relationships) in point of total 15 characteristics considered in this study were tested by using Minitab 18.1 (2017) statistics program [22].

\section{RESULTS AND DISCUSSION}

All three registered durum wheat varieties used as check materials in both sowing trials did not grow well and were infected with stem rust caused by the fungus Puccinia graminis f. sp. tritici which induces epidemic in Kastamonu province due to climatic conditions [23]. For this reason, enough samples for quality analysis of checks were not obtained and were excluded in the statistical analysis of trials. However, all einkorn lines sown in autumn and in spring grew very well and had very few symptoms of stem rust by presenting tolerance to this pathogen.

Table 1: Estimates of descriptive statistics for 15 morpho-agronomical, physical and nutritional characteristics of 45 einkorn lines sown in autumn and spring seasons of 2017/2018 in Kastamonu, Turkey

\begin{tabular}{|c|c|c|c|c|c|c|c|c|c|c|}
\hline \multirow{2}{*}{ Traits } & \multirow{2}{*}{$\begin{array}{c}\text { CV } \\
\%\end{array}$} & \multirow{2}{*}{ MS } & \multicolumn{4}{|c|}{ Lines sown in 2017 autumn } & \multicolumn{4}{|c|}{ Lines sown in 2018 spring } \\
\hline & & & Min & $\operatorname{Max}$ & Mean & $\begin{array}{l}\text { Standard } \\
\text { deviation }\end{array}$ & Min & Max & Mean & $\begin{array}{l}\text { Standard } \\
\text { deviation }\end{array}$ \\
\hline HT (\#days) & 1.43 & $194417 * * *$ & 204.00 & 212.00 & 207.62 & 1.85 & 109.00 & 117.00 & 114.67 & 2.83 \\
\hline $\mathrm{PH}(\mathrm{cm})$ & 7.51 & $5744 * * *$ & 94.00 & 120.00 & 103.16 & 5.62 & 68.00 & 98.00 & 87.18 & 7.21 \\
\hline LS & 46.79 & $69.34 * * *$ & 3.00 & 5.00 & 3.36 & 0.77 & 0.00 & 3.00 & 1.60 & 1.51 \\
\hline $\mathrm{SL}(\mathrm{cm})$ & 12.43 & $64 * * *$ & 4.00 & 7.40 & 5.92 & 0.69 & 3.00 & 6.00 & 4.23 & 0.55 \\
\hline NSS & 15.68 & $1345.6 * * *$ & 16.00 & 30.00 & 22.47 & 3.19 & 10.00 & 20.00 & 14.73 & 2.43 \\
\hline GGY (g) & 26.98 & $104312 * * *$ & 118.00 & 264.00 & 178.13 & 37.91 & 68.00 & 240.00 & 110.04 & 34.43 \\
\hline $\mathrm{AG}(\%)$ & 4.12 & $88 * * *$ & 26.67 & 31.67 & 28.44 & 1.24 & 26.67 & 33.33 & 30.41 & 1.52 \\
\hline GD (mm) & 3.03 & $0.098 * * *$ & 2.17 & 2.54 & 2.37 & 0.08 & 2.09 & 2.50 & 2.31 & 0.09 \\
\hline SGW (mg) & 6.61 & $121.62 * * *$ & 21.38 & 28.60 & 25.59 & 1.63 & 18.20 & 28.64 & 23.27 & 2.27 \\
\hline GMC (\%) & 1.97 & $0.14 \mathrm{~ns}$ & 10.28 & 11.12 & 10.83 & 0.18 & 10.13 & 11.43 & 10.76 & 0.31 \\
\hline $\mathrm{HI}(\%)$ & 34.78 & $551.87 * * *$ & -11.67 & -4.44 & -7.60 & 1.73 & -6.65 & 3.64 & -2.65 & 2.75 \\
\hline GPC (\%) & 5.48 & $11.66 * * *$ & 11.10 & 13.95 & 12.76 & 0.67 & 11.26 & 14.93 & 13.48 & 0.78 \\
\hline LCV & 0.98 & $7.29 * *$ & 88.01 & 92.37 & 90.66 & 0.96 & 86.98 & 92.13 & 90.09 & 1.07 \\
\hline $\mathrm{aCV}$ & 5.43 & $0.27 * *$ & 2.78 & 3.66 & 3.22 & 0.19 & 2.86 & 3.93 & 3.33 & 0.24 \\
\hline $\mathrm{bCV}$ & 2.65 & $2.03 * * *$ & 14.07 & 16.30 & 15.24 & 0.56 & 13.93 & 17.04 & 15.54 & 0.71 \\
\hline
\end{tabular}

$* * *$ significant at $\mathrm{P} \leq 0.001 ; * *$ significant at $0.001<\mathrm{P} \leq 0.01$; ns: not significant at $\mathrm{P}>0.05$ 
The results of analysis of variance (ANOVA) and the estimates of descriptive statistics, including mean, minimum and maximum values, coefficient of variations $(\mathrm{CVs})$ and standard deviations of 15 morpho-agronomical, physical and nutritional characteristics of 45 einkorn lines sown in autumn and spring seasons of 2017/2018 were presented at Table 1 . The ANOVA revealed highly significant $(\mathrm{P} \leq 0.001)$ differences among sowing seasons of einkorn lines in point of $\mathrm{HT}$, $\mathrm{PH}$, LS, SL, NSS, GGY, AG, GD, SGW, HI, GPC and bCV. There was also significantly $(\mathrm{P} \leq 0.01)$ difference among sowing seasons of einkorn lines in terms of their LCV and aCV except GMC. Highly significant differences for all characteristics have indicated the presence of considerable amount of variability among einkorn lines which plays an important role for the selection in crop breeding [24].

\subsection{Morpho-Agronomical Traits}

The CVs for six yield related morpho-agronomical traits ranged from $1.43 \%$ to $46.79 \%$ (Table 1). While the least CV belonged to HT, the most relative variable trait was LS, following by GGY (26.98\%), NSS (15.68\%), SL (12.43\%) and PH (7.51\%). Similar ordering of CV values was reported for days to flowering (4.17\%), plant height (10.58\%), spike length $(30.73 \%)$ and number of grains per spike (34.79\%) for einkorn populations evaluated at Haymana, Ankara Research Farm of TARM in 1999-2000 planting season [25]. The higher values of those coefficients confirm that these traits are more susceptible to change by the effects of different factors [26]. A minimum 10\% CV has been considered as a sign for wide diversity in wheat landraces [27]. Therefore, 45 einkorn lines in this study exhibited quite diversity in terms of SL, NSS, GGY and LS.

The values of mean square (MS) for all morpho-agronomic traits showed highly significant differences between sowing seasons of 45 einkorn lines (Table 1). This finding indicates the existence of a high degree of variability in the lines to be exploited in breeding program [28,29]. All of the einkorn lines in the trials flowered well when sown both in autumn and in spring. Lines sown in autumn and in spring headed between 204-212 (Avg. 208) days and 109-117 (Avg. 115) days after sowing, respectively. Due to especially hot weather (max. $29.1^{\circ} \mathrm{C}$ ) and less rainfall (total $21.2 \mathrm{~mm}$ ) conditions of İhsangazi in April 2018, as expected, lines sown in spring moved faster from vegetative growth stage to generative growth stage than those sown in autumn. It has been indicated that einkorn has limited tolerance to drought particularly after spike emergence [30] and its flag leaves show faster senescence under water stress conditions than other wheat species [31].

Plant height is an important trait for wheat breeding because it exhibits the growth performance of plants and affects grain yields. Modern high yielding cultivars are shorter than landraces. Environmental factors including cultivation practices also play a vital role in formation of the plant height [32]. The PHs of lines sown in autumn varied between 94 and $120 \mathrm{~cm}$ and the average $103 \mathrm{~cm}$ was measured. As a result of having shorter vegetative growth stage, lines sown in spring had average $16 \mathrm{~cm}$ shorter plants $(68-98 \mathrm{~cm}$, Avg. $87 \mathrm{~cm}$ ) than those sown in autumn. Consequently, lines sown in spring having shorter stems were observed to be more resistant to lodging, whereas those sown in autumn showed moderate lodging near harvesting time. Similar findings for plant heights above $100 \mathrm{~cm}$ and severe lodging for einkorn lines were reported in the literatures $[33,34,35]$. By evaluating morpho-agronomic variability of 1039 einkorn accessions obtained from several world gene banks, it was reported that wild form (T. monococcum subs. boeoticum) had the tallest plants (135 $\mathrm{cm}$ ), while hulless form (subs. sinskajae) and cultivated form (subs. monococcum) had the shortest plants $(65-85 \mathrm{~cm})$ [36]. It was also indicated in this report that in spite of their heights, many accessions $(65.8 \%)$ exhibited little or no lodging. On the other hand, according to the report of [37], most of 24 einkorn lines in the trials were almost completely lodged at harvesting time and the short line had the highest score of lodging whereas the semi-tall line had a score of 0 . Therefore, it was suggested that lodging in einkorn lines apparently was not associated with plant height.

Spike length, number of spikelet per spike, number of grains per spike and grain weight have crucial role in the yield potential of wheat [38]. The SLs of lines sown in autumn were between $4.00-7.40 \mathrm{~cm}$ (Avg. $5.92 \mathrm{~cm}$ ), whereas those of sown in spring varied between $3.00-6.00 \mathrm{~cm}$ with an average $4.23 \mathrm{~cm}$, which was $28.5 \%$ less than that of lines sown in autumn. Depending on SLs of lines, the NSS for lines sown in autumn and in spring were determined between 16-30 (Avg. 23) and 10-20 (Avg. 15), respectively. According to the findings of [25], slightly different values for SL (3.7-8.1 cm, Avg. $5.1 \mathrm{~cm}$ ) and number of grains per spike (13.6-36.6, Avg. 26.35) were obtained for einkorn populations planted in Haymana, Ankara on October 25, 1999. On the other hand, longer SLs (7.17-10.11 cm, Avg. of $8.73 \mathrm{~cm}$.) and more NSS (31-42, Avg. 36) were recorded for 22 einkorn wheat accessions evaluated in the Institute of Plant Genetic Resources "Konstantin Malkov"-Sadovo, Bulgaria [35]. Because NSS is quite variable yield related component among the einkorn genotypes, different values were reported in the literatures $[33,36]$.

Grain yield is the ultimate goal for wheat breeding. By comparing tetraploid and hexaploid wheats, diploid wheats have lower grain yields but higher biomass yields because they produce many infertile tillers and more seeds with smaller size [39] and grain yields increase by increasing ploidy levels [40]. In this research, GGY differed significantly between the sowing seasons of einkorn lines, thereby provides sufficient variability for further improvement. GGYs per plots were measured between 118-264 g (Avg. $178 \mathrm{~g}$ ) for lines sown in autumn and between 68-240 g (Avg. $110 \mathrm{~g}$ ) for those sown in 
spring. Apart from three lines, all other lines sown in autumn had more GGY than those of sown in spring which were also more variable. By considering the values of GGYs per plots, the mean GGYs per hectare of 45 lines sown in autumn and in spring were computed as $1.80 \mathrm{t} \mathrm{ha}^{-1}\left(1.19-2.67 \mathrm{t} \mathrm{ha}^{-1}\right)$ and $1.11 \mathrm{t} \mathrm{ha}^{-1}\left(0.69-2.42 \mathrm{t} \mathrm{ha}^{-1}\right)$, respectively. According to the report of [33], the average GGY of 21 einkorn lines grown for two years at Milano ranged from 2.04 to $2.83 \mathrm{tha}^{-1}$. Similarly, it was recorded the mean grain yield for einkorn varieties, namely MonLis, Mv Menket, Terzino and Tifi, at four diverse locations in southern Germany as $2.7 \mathrm{t} \mathrm{ha}^{-1}$ which was lower than those of emmer $\left(3.6 \mathrm{t} \mathrm{ha}^{-1}\right)$, spelt $\left(5.0 \mathrm{t} \mathrm{ha}{ }^{-1}\right)$, durum wheat $\left(6.1 \mathrm{t} \mathrm{ha}^{-1}\right)$ and bread wheat $\left(8.0 \mathrm{tha}^{-1}\right)$ [34].

\subsection{Physical and Nutritional Characteristics}

$\mathrm{CVs}$ for nine physical and nutritional characteristics of grains ranged from $0.98 \%$ to $34.78 \%$ which were considerably lower than those of morpho-agronomical traits (Table 1). While the least CV belonged to LCV, the most relative variable characteristic was HI, following by SGW (6.61\%), GPC (5.48\%), aCV (5.43\%), AG (4.12\%), GD (3.03\%), bCV (2.65\%) and GMC (1.97\%). Except for GMC, the values of MS for all other characteristics were significantly different between sowing seasons of 45 einkorn lines.

The AG in einkorn samples were determined between 26.67-31.67\% (Avg. 28.44\%) for lines sown in autumn and between 26.67-33.33\% (Avg. 30.41\%) for those sown in spring. Although the AG varied between lines, its average of lines sown in spring was around $7 \%$ more than that of lines sown in autumn. Since einkorn is a hulled wheat species, farmers, millers and traders should be aware of AG when making their choice for einkorn materials.

The values of GMC of lines sown in autumn and in spring were between 10.28-11.12\% (Avg. 10.83\%) and 10.13$11.43 \%$ (Avg. 10.76\%), respectively. No significant difference was found in point of GMCs between lines sown in autumn and spring. It was observed that lines sown in spring reached to harvest maturity very quickly due to hot weather conditions during maturation.

Based on physical properties of grains identified by SKCS, the values for GD of lines sown in autumn and in spring varied between 2.17-2.54 mm (Avg. $2.37 \mathrm{~mm}$ ) and 2.09-2.50 mm (Avg. $2.31 \mathrm{~mm}$ ), respectively. The average GD of lines sown in spring was $2.5 \%$ less than that of lines sown in autumn. As a result, SGWs of lines were measured between 21.38 $28.60 \mathrm{mg}$ (Avg. $25.59 \mathrm{mg}$ ) when they were sown in autumn and between 18.20-28.64 mg (Avg. $23.27 \mathrm{mg}$ ) when they were sown in spring. Consistent with grain diameters, the average SGW of lines sown in spring was $9 \%$ less than those of sown in autumn and had more variation. According to the report of [41], kernel diameter and thousand grain weight (TGW) of einkorn samples selected from Kastamonu were 2.90-3.93 mm (Avg. $3.37 \mathrm{~mm}$ ) and 29.10-32.40 g (Avg. $30.82 \mathrm{~g}$ ), respectively. On the other hand, it was reported the average thousand kernel weight (TKW) for einkorn populations grown in Haymana, Ankara as 32.26 g (28.46-38.83 g) [25]. It is well known that wheat grain diameter and weight, which are the principal determinant factors of the yield, have changed depending on genotype, environmental conditions and agronomic practices.

The values of $\mathrm{HI}$ varied between $-11.67 \%$ and $-4.44 \%$ (Avg. $-7.60 \%$ ) for lines sown in autumn and between $-6.65 \%$ and $3.64 \%$ (Avg. -2.65\%) for those sown in spring. These values have demonstrated an extra soft texture of grains for all lines. Although HI values for all lines sown in both autumn and spring were to be found much lower than that of "very soft" bread wheat, lines sown in spring had relatively harder grains than those sown in autumn. An important quality property of einkorn grain is its extra soft texture [42]. Puroindoline A (Pin-A) and puroindoline B (Pin-B), two $\alpha$-helical, tryptophan- and cysteine-rich isoforms belonging to the $2 \mathrm{~S}$ super-family of seed proteins are the principal determinant factors of einkorn grain extra-soft texture [43]. It was reported that compared to bread wheat, einkorn accessions showed an increase of 3.2- and 2.7-fold in Pin-A and Pin-B levels, respectively [44]. Another important characteristic of einkorn is the presence of an einkorn trypsin inhibitor (ETI) in the A-PAGE pattern of starch-bound proteins which absent in other cultivated wheats [8]. According to the report of [44], puroindolines and ETI work as the actual casual agents of the extrasoft texture of einkorn kernels by reducing the strength of the adhesion between the starch granule surface and the surrounding matrix.

Einkorn has the potential to produce high protein contents [34]. In this research, GPCs varied between 11.10-13.95\% (Avg. 12.76\%) for lines sown in autumn and between 11.26-14.93\% (Avg. 13.48\%) for those sown in spring. By comparing two sowing seasons, as expected grain protein contents of lines sown in spring, which had relatively smaller, lighter and harder kernels, were to be found higher than those of sown in autumn. It is known that when the facultative wheat varieties are sown in spring, their generative growth stage is shorter than that of sown in autumn and low starch has accumulated in their grains because of having shorter physical maturity stage as well. Therefore, grains of einkorn lines sown in spring had lower kernel weight but higher protein content than those of sown in autumn. It was reported that 14 einkorn populations collected from Kastamonu had longer plant heights $(71.3 \pm 0.68 \mathrm{~cm})$ with prostrate habitus, lower plant yields $(0.57 \pm 0.07 \mathrm{~g})$ but incredibly higher protein ratios $(17.2 \pm 0.14 \%)$ compared to those of registered durum and bread wheat 
check cultivars $(68.1 \pm 0.53 \mathrm{~cm}, 1.48 \pm 0.11 \mathrm{~g}, 11.08 \pm 0.12 \%$, respectively) in their spring planted field experiment in Kayseri province located in the Central Anatolia [40].

Although bCV was found to be higher for some lines sown in autumn and for some lines sown in spring, generally it was higher in lines sown in spring than those sown in autumn. The bCV reflects yellow endosperm color caused by carotenoid pigments. The carotenoid content of einkorn is 2-4 fold higher than non-einkorn wheats [45]. Lightness (LCV) and redness $(\mathrm{aCV})$ values showed relatively less differences between lines sown in autumn and in spring.

\subsection{Correlations between Characteristics}

Most of the correlation coefficients between 15 morpho-agronomical, physical and nutritional characteristics of 45 einkorn lines sown in autumn and spring seasons were significant (Table 2). HT was positively correlated with PH $(0.780 * *)$, SL $\left(0.812^{* * *}\right)$, NSS $\left(0.811^{* * *}\right)$, LS $\left(0.585^{* * *}\right)$, GGY $(0.693 * * *)$, GD $(0.369 * * *)$ and SGW $(0.519 * * *)$, whereas negatively correlated with $\mathrm{HI}(-0.734 * * *)$, GPC $(-0.452 * * *)$ and AG $(-0.572 * * *)$ at $\mathrm{P} \leq 0.001$. Einkorn lines sown in autumn, which exhibited average 93 days more heading time than that of sown in spring, had taller plants showing more lodging susceptibility and higher gross grain yield but less amount of glume and grain protein content with softer texture. According to the findings of [36], the heading date of 1039 einkorn accessions was positively correlated with number of spikelets per spike and spike density.

PH showed strongly positive correlations with SL $(0.834 * *)$, NSS $(0.839 * * *)$, LS $(0.524 * * *)$, GGY $(0.757 * * *)$, GD $(0.519 * * *), \mathrm{SGW}(0.622 * * *)$ and negative correlations with HI $(-0.689 * * *)$, GPC $(-0.439 * * *)$ and AG $(-0.548 * * *)$ at $\mathrm{P} \leq 0.001$. Even though taller plants were more susceptible to lodging, they provided higher gross grain yields by producing longer spikes within more spikelets and heavier grains but less glume and protein contents. Accordingly, LS was positively correlated with SL $(0.491 * * *)$, NSS $(0.539 * * *)$, GGY $\left(0.370^{* * *}\right)$ and negatively correlated with HI $(-0.539 * * *)$ and AG $\left(-0.449^{* * *}\right)$ at $\mathrm{P} \leq 0.001$. Therefore, einkorn lines having longer spikes with more spikelets were more susceptible to lodging when they were exposed to heavy rainfall and wind near harvesting time.

Table 2: Correlation coefficients between 15 morpho-agronomical, physical and nutritional characteristics of 45 einkorn lines sown in autumn and spring seasons of 2017/2018 in Kastamonu, Turkey

\begin{tabular}{|c|c|c|c|c|c|c|c|c|c|c|c|c|c|c|}
\hline & $\mathbf{P H}$ & SL & NSS & $\mathbf{L S}$ & GGY & HI & GMC & GD & SGW & GPC & LCV & $\mathrm{aCV}$ & bCV & $\mathbf{A G}$ \\
\hline HT & $\begin{array}{c}0.780 \\
* * *\end{array}$ & $\begin{array}{c}0.812 \\
\text { *** }\end{array}$ & $\begin{array}{c}0.811 \\
* * *\end{array}$ & $\begin{array}{c}0.585 \\
* * *\end{array}$ & $\begin{array}{c}0.693 \\
\text { *** }\end{array}$ & $\begin{array}{c}-0.734 \\
* * *\end{array}$ & $\begin{array}{c}0.169 \\
\text { ns }\end{array}$ & $\begin{array}{c}0.369 \\
* * *\end{array}$ & $\begin{array}{c}0.519 \\
* * *\end{array}$ & $\begin{array}{c}-0.452 \\
* * *\end{array}$ & $\begin{array}{c}0.270 \\
* *\end{array}$ & $\begin{array}{c}-0.253 \\
*\end{array}$ & $\begin{array}{c}-0.227 \\
*\end{array}$ & $\begin{array}{c}-0.572 \\
* * *\end{array}$ \\
\hline PH & & $\begin{array}{c}0.834 \\
* * *\end{array}$ & $\begin{array}{c}0.839 \\
* * *\end{array}$ & $\begin{array}{c}0.524 \\
* * *\end{array}$ & $\begin{array}{c}0.757 \\
* * *\end{array}$ & $\begin{array}{c}-0.689 \\
* * *\end{array}$ & $\begin{array}{c}0.274 \\
* *\end{array}$ & $\begin{array}{c}0.519 \\
* * *\end{array}$ & $\begin{array}{c}0.622 \\
* * *\end{array}$ & $\begin{array}{c}-0.439 \\
* * *\end{array}$ & $\begin{array}{c}0.300 \\
* *\end{array}$ & $\begin{array}{c}-0.295 \\
* *\end{array}$ & $\begin{array}{c}-0.244 \\
*\end{array}$ & $\begin{array}{c}-0.548 \\
* * *\end{array}$ \\
\hline SL & & & $\begin{array}{c}0.944 \\
* * *\end{array}$ & $\begin{array}{c}0.491 \\
* * *\end{array}$ & $\begin{array}{c}0.719 \\
* * *\end{array}$ & $\begin{array}{c}-0.683 \\
* * *\end{array}$ & $\begin{array}{c}0.216 \\
*\end{array}$ & $\begin{array}{c}0.349 \\
* * *\end{array}$ & $\begin{array}{c}0.563 \\
* * *\end{array}$ & $\begin{array}{c}-0.316 \\
* *\end{array}$ & $\begin{array}{c}0.230 \\
*\end{array}$ & $\begin{array}{c}-0.244 \\
*\end{array}$ & $\begin{array}{c}-0.274 \\
* *\end{array}$ & $\begin{array}{c}-0.504 \\
* * *\end{array}$ \\
\hline NSS & & & & $\begin{array}{c}0.539 \\
* * *\end{array}$ & $\begin{array}{c}0.715 \\
* * *\end{array}$ & $\begin{array}{c}-0.684 \\
* * *\end{array}$ & $\begin{array}{c}0.148 \\
\text { ns }\end{array}$ & $\begin{array}{c}0.331 \\
* * *\end{array}$ & $\begin{array}{c}0.518 \\
* * *\end{array}$ & $\begin{array}{c}-0.313 \\
* *\end{array}$ & $\begin{array}{c}0.244 \\
*\end{array}$ & $\begin{array}{c}-0.231 \\
*\end{array}$ & $\begin{array}{l}-0.250 \\
\quad *\end{array}$ & $\begin{array}{c}-0.507 \\
* * *\end{array}$ \\
\hline LS & & & & & $\begin{array}{c}0.370 \\
* * *\end{array}$ & $\begin{array}{c}-0.539 \\
* * *\end{array}$ & $\begin{array}{c}-0.290 \\
* *\end{array}$ & $\begin{array}{c}0.080 \\
\mathrm{~ns}\end{array}$ & $\begin{array}{c}0.131 \\
\mathrm{~ns}\end{array}$ & $\begin{array}{c}-0.086 \\
\text { ns }\end{array}$ & $\begin{array}{c}0.149 \\
n s\end{array}$ & $\begin{array}{c}-0.071 \\
\mathrm{~ns}\end{array}$ & $\begin{array}{c}-0.325 \\
* *\end{array}$ & $\begin{array}{c}-0.449 \\
* * *\end{array}$ \\
\hline GGY & & & & & & $\begin{array}{c}-0.552 \\
* * *\end{array}$ & $\begin{array}{c}0.308 \\
* *\end{array}$ & $\begin{array}{c}0.327 \\
* *\end{array}$ & $\begin{array}{c}0.470 \\
* * *\end{array}$ & $\begin{array}{c}-0.432 \\
* * *\end{array}$ & $\begin{array}{c}0.290 \\
* *\end{array}$ & $\begin{array}{c}-0.257 \\
*\end{array}$ & $\begin{array}{c}-0.205 \\
\mathrm{~ns}\end{array}$ & $\begin{array}{c}-0.478 \\
* * *\end{array}$ \\
\hline HI & & & & & & & $\begin{array}{c}-0.176 \\
\mathrm{~ns}\end{array}$ & $\begin{array}{c}-0.365 \\
* * *\end{array}$ & $\begin{array}{c}-0.535 \\
* * *\end{array}$ & $\begin{array}{c}0.204 \\
\mathrm{~ns}\end{array}$ & $\begin{array}{c}-0.118 \\
\mathrm{~ns}\end{array}$ & $\begin{array}{c}0.208 \\
*\end{array}$ & $\begin{array}{c}0.276 \\
* *\end{array}$ & $\begin{array}{c}0.549 \\
* * *\end{array}$ \\
\hline GMC & & & & & & & & $\begin{array}{c}0.489 \\
* * *\end{array}$ & $\begin{array}{c}0.556 \\
* * *\end{array}$ & $\begin{array}{c}-0.272 \\
* *\end{array}$ & $\begin{array}{c}0.288 \\
* *\end{array}$ & $\begin{array}{c}-0.340 \\
* * *\end{array}$ & $\begin{array}{c}-0.119 \\
\mathrm{~ns}\end{array}$ & $\begin{array}{c}-0.084 \\
n s\end{array}$ \\
\hline GD & & & & & & & & & $\begin{array}{c}0.894 \\
* * *\end{array}$ & $\begin{array}{c}-0.286 \\
* *\end{array}$ & $\begin{array}{c}0.237 \\
*\end{array}$ & $\begin{array}{c}-0.266 \\
*\end{array}$ & $\begin{array}{c}0.017 \\
\text { ns }\end{array}$ & $\begin{array}{c}-0.420 \\
* * *\end{array}$ \\
\hline SGW & & & & & & & & & & $\begin{array}{c}-0.305 \\
* *\end{array}$ & $\begin{array}{c}0.275 \\
* *\end{array}$ & $\begin{array}{c}-0.332 \\
* * *\end{array}$ & $\begin{array}{c}-0.115 \\
\mathrm{~ns}\end{array}$ & $\begin{array}{c}-0.447 \\
* * *\end{array}$ \\
\hline GPC & & & & & & & & & & & $\begin{array}{c}-0.119 \\
\mathrm{~ns}\end{array}$ & $\begin{array}{c}0.191 \\
\mathrm{~ns}\end{array}$ & $\begin{array}{c}-0.202 \\
\mathrm{~ns}\end{array}$ & $\begin{array}{c}0.263 \\
*\end{array}$ \\
\hline LCV & & & & & & & & & & & & $\begin{array}{l}-0.787 \\
* * *\end{array}$ & $\begin{array}{c}-0.460 \\
* * *\end{array}$ & $\begin{array}{c}-0.045 \\
\text { ns }\end{array}$ \\
\hline $\mathbf{a C V}$ & & & & & & & & & & & & & $\begin{array}{c}0.479 \\
* * *\end{array}$ & $\begin{array}{c}0.010 \\
\mathrm{~ns}\end{array}$ \\
\hline bCV & & & & & & & & & & & & & & $\begin{array}{c}0.089 \\
\text { ns }\end{array}$ \\
\hline
\end{tabular}

$* * *$ significant at $\mathrm{P} \leq 0.001 ; * *$ significant at $0.001<\mathrm{P} \leq 0.01 ; *$ significant at $0.01<\mathrm{P} \leq 0.05$; ns: not significant at $\mathrm{P}>0.05$

Grain yield is a complicated trait affected by a number of yield contributing characteristics. As expected, GGY and yield related characteristics i.e. HT, PH, SL, NSS, GD and SGW were positively correlated with each other and negatively correlated with $\mathrm{AG}, \mathrm{HI}$ and GPC $(\mathrm{P} \leq 0.001)$. GGY showed strongly positive correlations with HT $(0.693 * * *)$, PH 
$(0.757 * * *)$, SL $(0.719 * * *)$, NSS $\left(0.715^{* * *}\right)$, SGW $(0.470 * * *)$, GD $(0.327 * *)$ and negative correlations with HI $(-$ $0.552 * * *)$, AG $(-0.478 * * *)$ and GPC (-0.432***). In this manner, einkorn lines sown in autumn, which exhibited average 93 days more heading time and taller plants, provided higher gross grain yields by producing longer spikes with more spikelets including heavier grains but less glume and protein content than those sown in spring. Similarly, it was reported that the relationship between thousand grain weight, number of spikelets per spike, grain weight per spike and grain yield per plant were to be found significant for 22 einkorn lines [35].

Protein content is one of the most important quality parameters in wheat which has an impact on the nutritional value of the grain and technological property of the flour. In this research, GPC were negatively correlated with GGY $(-0.432 * * *)$ and all yield related characteristics. Compared to sowing in autumn, einkorn lines sown in spring, which formed shorter plants and headed in a shorter period, had lower gross grain yield but higher grain protein content. The highest GPC value of $14.93 \%$ was determined in the line sown in spring with $98 \mathrm{~g} \mathrm{GGY}\left(0.99 \mathrm{t} \mathrm{ha}^{-1}\right)$. In the same way, HI and AG showed significantly negative correlations with GGY $\left(-0.552 * * *\right.$ and $-0.478^{* * *}$, respectively) and all yield related traits.

GMC was positively correlated with GD $(0.489 * * *)$, SGW $\left(0.556^{* * *}\right)$, and negatively correlated with aCV ($0.340 * * *)$ at $\mathrm{P} \leq 0.001$. Increasing of moisture content in bigger and heavier grains resulted in reducing of redness of kernel. While LCV showed negative correlations with $\mathrm{aCV}(-0.787 * * *)$ and $\mathrm{bCV}(-0.460 * * *)$, the positive correlation was found between $\mathrm{aCV}$ and $\mathrm{bCV}(0.479 * * *)$ at $\mathrm{P} \leq 0.001$.

\section{CONCLUSION}

Local 45 cultivated einkorn lines sown in autumn 2017 and spring 2018 in İhsangazi, Kastamonu/Turkey presented considerable variations in point of morphological, agronomical and quality characteristics, which can be used for breeding programs. All of the einkorn lines in the trials showed "facultative" growth habit because they flowered well when sown both in autumn and in spring. Einkorn lines sown in autumn, which exhibited more heading time and taller plants, provided higher gross grain yields by producing longer spikes with more spikelets including heavier grains but less protein content than those sown in spring. Even though lines sown in spring had generally lower gross grain yield, they showed more resistance to lodging due to forming shorter plants and provided higher grain quality, i.e. higher grain protein content and harder grain. In order to enable sustainable future use of einkorn, further breeding research is strongly suggested for reduction of plant height to avoid lodging and improvement of grain yield to compete with shorter and high yielding modern wheat cultivars. Besides, valuable characteristics of einkorn lines, particularly higher grain protein content and tolerance to stem rust, can be exploited in breeding programs of durum and bread wheat.

\section{ACKNOWLEDGEMENT}

This research was supported by Kastamonu Chamber of Commerce \& Industry (KATSO) under Grant number KATSO-2017/5379 and carried out by the cooperation between Kastamonu University, Central Research Institute for Field Crops and Kastamonu Province Directorate of Agriculture \& Forestry. In order to collect cultivated einkorn wheat spikes from farmers' fields in Kastamonu, essential research permission for plant genetic resources was obtained from General Directorate of Agricultural Research \& Policies (TAGEM), Republic of Turkey, Ministry of Agriculture \& Forestry. The first author thanks the funding agency for their grant, TAGEM for research permission, the project partners for their institutional and technical supports, and the farmers for providing einkorn collection materials.

\section{REFERENCES}

[1] Hammer, K., Filatenko, A.A. and Pistrick, K. "Taxonomic remarks on Triticum L. and xTriticosecale Wittm.” Genetic Resources and Crop Evolution vol.58, pp.3-10, 2011.

[2] Szabó, A.T. and Hammer, K. "Notes on the taxonomy of farro: Triticum monococcum, T. dicoccon and T. spelta" In: Proceedings of the First International Workshop on Hulled Wheats: Promoting the conservation and use of underutilized and neglected crops, pp. 2-40, 1996.

[3] Filatenko, A.A. and Kurkiev, U.K. “A new species - Triticum sinskajae A. Filat. et Kurk.” Trudi po Prikladnoi Botanike Genetike i Selektsii vol.54, no.1, pp.239-241, 1975.

[4] Mac Key, J. "Wheat: its concept, evolution and taxonomy" In: Durum wheat breeding: Current approaches and future strategies, vol.1, pp. 3-61, 2005. 
[5] Taenzler, B., Esposti, R.F., Vaccino, P., Brandolini, A., Effgen, S., Heun, M., Schafer-Pregl, R., Borghi, B. and Salamini, F. "Molecular linkage map of einkorn wheat: mapping of storage-protein and soft-glume genes and bread-making quality QTLs" Genetics Research vol.80, no.2, pp.131-143, 2002.

[6] Grausgruber, H., Sailer, C., Ghambashidze, G., Bolyos, L. and Ruckenbauer, P. "Genetic variation in agronomic and qualitative traits of ancient wheat" In: Proceedings of the $17^{\text {th }}$ EUCARPIA General Congress: Genetic Variation for Plant Breeding, pp.19-22, 2004.

[7] Heun, M., Schäfer-Pregl, R., Klawan, D., Castagana, R., Accerbi, M., Borghi, B. and Salamini, F. "Site of einkorn wheat domestication identified by DNA fingerprinting" Science vol.278, pp.1312-1314, 1997.

[8] Zaharieva, M. and Monneveux, P. "Cultivated einkorn wheat (Triticum monococcum L. subs. monococcum): the long life of a founder crop of agriculture" Genetic Resources and Crop Evolution vol.61, no.3, pp.677-706, 2014.

[9] Golovnina, K.A., Kondratenko, E.Y., Blinov, A.G. and Goncharov, N.P. "Molecular characterization of vernalization loci VRN1 in wild and cultivated wheats" BMC Plant Biology vol.10, pp.168-182, 2010.

[10] Stagnari, F., Codianni, P. and Pisante, M. "Agronomic and kernel quality of ancient wheats grown in central and southern Italy” Cereal Research Communications vol.36, pp.313-326, 2008.

[11] Grausgruber, H., Preinerstorfer, B., Geleta, N., Leopold, L., Eticha, F., Kandler, W., Schuhmacher, R., Bointner, H. and Siebenhandl-Ehn, S. "Hulled wheats in organic agriculture - Agronomic and nutritional considerations" In: $8^{\text {th }}$ International Wheat Conference, Abstracts of oral and poster presentations, pp.41-42, 2010.

[12] Perrino, P., Laghetti, G., D’Antuono, L.F., Al Ajlouni, M., Kanbertay, M., Szabó, A.T. and Hammer, K. "Ecogeographical distribution of hulled wheat species" In: Proceedings of the First International Workshop on Hulled Wheats: Promoting the conservation and use of underutilized and neglected crops, pp.100-118, 1996.

[13] Karagöz, A. "Wheat landraces of Turkey” Emirates Journal of Food and Agriculture vol.26, no.2, pp.149-156, 2014.

[14] Belay, G., Tesemma, T., Bechere, E. and Mitiku, D. "Natural and human selection for purple-grain tetraploid wheats in the Ethiopian highlands" Genetic Resources and Crop Evolution vol.42, pp.387-391,1995.

[15] Keller, L., Schmid, J.E. and Keller, E.R. “Are cereal landraces a source for breeding?” Landwirtschaft Schweiz vol.4, pp.197-202, 1991.

[16] Newton, A.C., Akar, T., Baresel, J.P., Bebeli, P.J., Bettencourt, E., Bladenopoulos, K.V., Czembor, J.H., Fasoula, D.A., Katsiotis, A., Koutis, K., Koutsika-Sotiriou, M., Kovacs, G., Larsson, H., Pinheiro de Carvalho, M.A.A., Rubiales, D., Russell, J., Dos Santos, T.M.M. and Vaz Patto, M.C. "Cereal landraces for sustainable agriculture. A review" Agronomy for Sustainable Development vol.30, pp.237-269, 2010.

[17] DeLacy, I.H., Skovmand, B. and Huerto, J. "Characterization of Mexican wheat landraces using agronomically useful attributes” Genetic Resources and Crop Evolution vol.47, pp.591-602, 2000.

[18] Savac1, G. and Sarıyıldı, T. "A comparison of soil organic carbon and total nitrogen stock capacity between cultivated, agriculture and forest soils” Journal of Innovative Science and Engineering vol.2, no.2, pp.51-60, 2018.

[19] Anonymous "Guidelines for the conduct of tests for distinctness, uniformity and stability. Wheat" TG/3/12, UPOV Code(s): TRITI_AES. International Union for the Protection of New Varieties of Plants (UPOV), Geneva, Switzerland, 2017.

[20] Anonymous "Approved methods of the American Association of Cereal Chemists (AACC)" $10^{\text {th }}$ edn. Method No: 10-10-B, 26-50, 14-50, 46-30, 54-21, 54-40, 55-31, 74-09. St. Paul, MN, USA, 2000.

[21] Anonymous "Standard practice for obtaining spectrophotometric data for object-color evaluation" American Society for Testing and Materials (ASTM) Method No: E 1164. West Conshohocken, PA, USA, 2002.

[22] Düzgüneş, O., Kesici, T., Kavuncu, O. and Gürbüz, F. Methods of research and experiment (Statistical methods II) Lecture Book No: 1021 Publications of Agricultural Faculty, Ankara University, Ankara, Turkey, 1987.

[23] Mert, Z., Karakaya, A., Düşünceli, F., Akan, K. and Çetin, L. "Determination of Puccinia graminis f. sp. tritici races of wheat in Turkey” Turkish Journal of Agriculture and Forestry vol.36, pp.107-120, 2012. 
[24] Alam, M.A., Khan, A.A., Alam, M.K., Sarker, Z.I. and Rahman, M.M. "Variability and diversity studies in durum wheat (Triticum durum)” Journal of Science and Technology (Dinajpur) vol.11, pp.1-5, 2013.

[25] Karagöz, A. and Zencirci, N. "Variation in wheat (Triticum spp.) landraces from different altitudes of three regions of Turkey” Genetic Resources and Crop Evolution vol.52, pp.775-785, 2005.

[26] Desheva, G. "Morphological and agronomical characterization of common wheat landraces (Triticum aestivum L.) from the National Wheat Collection of Bulgaria" Emirates Journal of Food and Agriculture vol.26, no.2, pp.164-169, 2014.

[27] Dotlacil, L., Hermuth, J., Stehno, Z. and Manev, M. "Diversity in European winter wheat landraces and obsolete cultivars" Czech Journal of Genetics and Plant Breeding vol.16, pp.29-36, 2000.

[28] Kumar, N., Markar, S. and Kumar, V. "Studies on heritability and genetic advance estimates in timely sown bread wheat (Triticum aestivum L.)” Bioscience Discovery vol.5, no.1, pp.64-69, 2014.

[29] Ahmed, I., Kumar, J., Goel, N., Mishra, V.K. and Sharma, P.K. "Characterization of variability, genetic divergence and character association in wheat germplasm of SWRS in respect of nutrition and yield traits" International Journal of Current Microbiology and Applied Sciences vol.7, no.5, pp.303-314, 2018.

[30] Dorofeev, V.F., Udachin, R.A., Semenova, L.V., Novikova, M.V., Grazhdaninova, O.D., Shitova, I.P., Merezhko, A.F. and Filatenko, A.A. World wheat. Agropromizdat, Leningrad, 1987.

[31] Adu, M.O., Sparkes, D.L., Parmar, A. and Yawson, D.O. "Stay green in wheat: comparative study of modern bread wheat and ancient wheat cultivars” ARPN Journal of Agricultural and Biological Science vol.6, no.9, pp.16-24, 2011.

[32] Watanabe, N. "Breeding opportunities for early, free-threshing and semi-dwarf Triticum monococcum L." Euphytica vol.213, pp.201-211, 2017.

[33] Castagna, R., Borghi, B., Di Fonzo, N., Heun, M. and Salamini, F. "Yield and related traits of einkorn (T. monococcum ssp. monococcum) in different environments” European Journal of Agronomy vol.4, no.3, pp.371-378, 1995.

[34] Longin, C.F.H., Ziegler, J., Schweiggert, R., Koehler, P., Carle, R. and Würschum, T. “Comparative study of hulled (einkorn, emmer, and spelt) and naked wheats (durum and bread wheat): agronomic performance and quality traits" Crop Science vol.56, pp.302-311, 2016.

[35] Desheva, G. and Kyosev, B. "Study of genetic parameters and association between characters in einkorn genotypes" Trakia Journal of Sciences vol.15, no.2, pp.141-148, 2017.

[36] Empilli, S., Castagna, R. and Brandolini, A. "Morpho-agronomic variability of the diploid wheat Triticum monococcum L." Plant Genetic Resources Newsletter vol.124, pp.36-40, 2000.

[37] Corbellini, M., Empilli, S., Vaccino, P., Brandolini, A., Borghi, B., Heun, M. and Salamini, F. "Einkorn characterization for bread and cookie production in relation to protein subunit composition" Cereal Chemistry vol.76, no.5, pp.727-733, 1999.

[38] Arya, V.K., Singh, J., Kumar, L., Nagar, S.S., Ahalawat, N.K. and Chand, P. "Genetic variability and heritability studies in relation to grain yield and its component traits in wheat (Triticum aestivum L.)" International Journal of Agricultural and Statistical Sciences vol.14, no.1, pp.215-222, 2018.

[39] Guzy, M.R., Ehdaie, B. and Waines, J.G. "Yield and its components in diploid, tetraploid and hexaploid wheats in diverse environments" Annals of Botany vol.64, pp.635-642, 1989.

[40] Gurcan, K., Demirel, F., Tekin, M., Demirel, S. and Akar, T. "Molecular and agro-morphological characterization of ancient wheat landraces of Turkey” BMC Plant Biology vol.17, pp.171-180, 2017.

[41] Ünal, H.G. "Some physical and nutritional properties of hulled wheat" Tarım Bilimleri Dergisi, Ankara Üniversitesi, Ziraat Fakültesi (Journal of Agricultural Sciences, Ankara University, Faculty of Agriculture) vol.15, no.1, pp.58-64, 2009.

[42] Pogna, N.E., Gazza, L., Corona, V., Zanier, R., Niglio, A., Mei, E., Palumbo, M. and Boggini, G. "Puroindolines and kernel hardness in wheat species" In: Wheat quality elucidation. American Association of Cereal Chemists (AACC), St Paul, MN, USA, pp.155-169, 2002. 
[43] Morris, C.F. "Puroindolines: the molecular genetic basis of wheat grain hardness" Plant Molecular Biology vol.48, pp.633-647, 2002.

[44] Taddei, F., Gazza, L., Conti, S., Muccilli, V., Foti, S. and Pogna, N.E. "Starch-bound 2S proteins and kernel texture in einkorn, Triticum monococcum ssp. monococcum" Theoretical and Applied Genetics vol.119, no.7, pp.1205-1212, 2009.

[45] Hidalgo, A. and Brandolini, A. "Nutritional properties of einkorn wheat (Triticum monococcum L.)" Journal of the Science of Food and Agriculture vol.94, pp.601-612, 2014. 